\title{
From the Sum of Near-Zero Energy Buildings to the Whole of a Near-Zero Energy Housing Settlement: The Role of Communal Spaces in Performance-Driven Design
}

\author{
Georgios Artopoulos $^{1}$, Gloria Pignatta ${ }^{2,3}$, Mattheos Santamouris ${ }^{4}$
}

How to cite: Artopoulos, G., Pignatta, G., Santamouris, M. 'From the Sum of NearZero Energy Buildings to the Whole of a Near-Zero Energy Housing Settlement: The Role of Communal Spaces in Performance-Driven Design.' Architecture_MPS, 2018, 14(1): 3, pp. 1-23. DOI: https://doi.org/10.14324/111.444.amps.2018v14i3.001.

Published: 01 November 2018

\section{Peer Review:}

This article has been peer reviewed through the journal's standard Editorial double blind peer review.

\section{Copyright:}

(C) 2018, The Author(s). This is an Open Access article distributed under the terms of the Creative Commons Attribution License (CC-BY) 4.0 https://creativecommons.org/licenses/by/4.0/, which permits re-use, distribution and reproduction in any medium, provided the original author and source are credited • DOI: https://doi.org/10.14324/111.444.amps.2018v14i3.001

\section{Open Access:}

Architecture_MPS is a peer-reviewed open access journal.

\footnotetext{
1 The Cyprus Institute, Science and Technology in Archaeology Research Center (STARC), Cyprus

2 UNSW Sydney, Australia

${ }^{3}$ Singapore-MIT Alliance for Research and Technology, Singapore

${ }^{4}$ UNSW Sydney, Australia
} 


\title{
Title: From the Sum of Near- Zero Energy Buildings to the Whole of a Near-Zero Energy Housing Settlement: The Role of Communal Spaces in Performance-Driven Design
}

\author{
Authors: Georgios Artopoulos ${ }^{1}$, \\ Gloria Pignatta ${ }^{2,3}$, Mattheos Santamouris ${ }^{4}$
}

Architecture_media_politics_society. vol.14, no. 3.

November 2018

Affiliations: ${ }^{1}$ The Cyprus Institute, Science and Technology in Archaeology Research Center (STARC), Cyprus ${ }^{2}$ UNSW Sydney, Australia

${ }^{3}$ Singapore-MIT Alliance for Research and Technology, Singapore

${ }^{4}$ UNSW Sydney, Australia

\section{Abstract}

Almost a century ago Modernism challenged the structure of the city and reshaped its physical space in order to, amongst other things, accommodate new transportation infrastructure and road networks proclaiming the, 


\section{Amps}

nowadays much-debated 'scientificated' pursuit of efficiency for the city. This transformation has had a great impact on the way humans still design, move in, occupy and experience the city. Today major cities in Europe, such as Paris and London, are considering banning vehicles from their historic centers. In parallel, significant effort is currently underway internationally by designers, architects, and engineers to integrate innovative technologies and sophisticated solutions for energy production, management, and storage, as well as for efficient energy consumption, into the architecture of buildings. In general, this effort seeks for new technologies and design methods (e.g., DesignBuilder with EnergyPlus simulation engine; Rhicoceros3D with Grasshopper plugin and Ecotect, Radiance and EnergyPlus tools) that would enable a holistic approach to the spatial design of Near-Zero Energy buildings, so that their ecological benefits are an added value to the architectural design and a building's visual, and material, impact on its surrounding space. The paper inquires how the integration of such technological infrastructure and performance-orientated interfaces changes yet again the structure and form of cities, and to what extent it safeguards social rights and enables equal access to common resources. Drawing from preliminary results and initial considerations of ongoing research that involve the construction of four innovative NZE settlements across Europe, in the context of the EU-funded ZERO-PLUS project, this paper discusses the integration of novel infrastructure in communal spaces of these settlements. In doing so, it contributes to the debate about smart communities and their role in the sustainable management of housing developments and settlements that are designed and developed with the concept of smart territories.

DOI: 10.14324/111.444.amps.2018v14i3.001, (C) 2018, The Authors. This is an Open Access article distributed under the terms of the Creative Commons Attribution License, which permits unrestricted use, distribution, and reproduction in any medium, provided the original author and source are credited.

ARCHITECTURE_MEDIA_POLITICS_SOCIETY Vol. 14 No. 3 November 2018 


\title{
Title: From the Sum of Near-Zero Energy Buildings to the Whole of a Near-Zero Energy Housing Settlement: Accessing Data in Performance-Driven Design
}

\author{
Authors: Georgios Artopoulos, Gloria Pignatta, Mattheos \\ Santamouris
}

Architecture_media_politics_society. vol. 14, no. 3 .

November 2018

\section{Introduction}

This article reflects on the impact that the integration of ICT (Information and Communication Technologies) in the operation and management of urban environment has on accessing common resources for citizens and its users. The article starts with a brief reference to the historical context of this relationship (of "augmenting" the built environment according to technological drivers and needs in order to provide "better" interaction experience), and then it moves on to present a contemporary example of integrated systems design that provides access to common resources through appropriate solutions of data management. Almost a century ago, Modernism challenged the structure of the city and reshaped its physical space, in order to - between other pressing needs - approach the reorganization of its infrastructure in a more rational way for a healthy, safe, and easy environment to live in. ${ }^{1}$ As they did so, architects proclaimed the, nowadays much-debated, "scientificated" understanding of the operation of the city, ${ }^{2,3}$ by likening its infrastructure to electrical circuit diagrams - in an attempt to rationalize its operation and provide access to its resources in a controlled, secure, and efficient way. Today, architects are employing data-driven (analytical) methodologies and "smart technologies" in order to upgrade urban infrastructures in a way that will allow for an easy, both energy consumption-wise and socially sustainable, everyday experience of the city. ${ }^{4,5}$

An important key enabling technology for smart cities is the Internet of Things (IoT). The integration of ICT is fundamental in a city since it supports the spread of concepts like Internet of Things (IoT), Artificial Intelligence (AI), 


\section{Amps}

and machine learning that enable technology to work with big data and learn from them to find useful patterns and correlation able to modify and influence the everyday life in a city. In this way, the city becomes active and resilient against every type of external and internal change.

Outside Europe, and in developing countries, new cities are under construction to accommodate new waves of urbanization and enable economic growth, both of which raise the demand for housing settlements, ${ }^{6}$ with China and India to mention but two examples of this pressing need (e.g., Yinchuan, China's first metropolis that is regulated as a "Smart City," and Gujarat International Finance-Tec City in India). Most up-and-coming smart cities in the world are located in Asia, where specific smart city programs have been developed and are being implemented, such as in Singapore, Japan (Tokyo), South Korea (Seoul and Daejeon), and Taiwan (Taipei). In particular, China is expected to account for $50 \%$ of the smart cities in Asia (e.g., Hong Kong, Beijing, Shanghai, and many others). In both scenarios, of upgrading/"smartening" existing infrastructures and creating new ones, there is once again a hegemonic narrative emerging among architects, engineers, and city stakeholders, similar to the one that occurred a century ago. This narrative promotes the benefits of technological approaches in mastering the city's complexity, and relies on the affordances of the quantified simulacrum of the city through numerically operating tools for controlling and optimizing the big data of its operation.

Smart cities will use the techniques of "smartness" to leverage their regional competitive advantages. Instead of being speed-of-light flat-world platforms, all global and multicultural, they'll be digitally gated communities, with "code as law" that is as crooked, complex, and deceitful as a Facebook privacy chart. ${ }^{7}$

This article claims there is a direct link between the sustainable operation of a city's infrastructures (in terms of their performance) and its resilience as an aggregate of socially active communities, through the access of the latter to communal resources in their respective built environment. In this context, the article will attempt, through an exemplar case of developing near-zero energy (NZE) settlements, to reflect on the integration of ICT in the management of performance-driven operations of these settlements' infrastructure and to discuss resulting issues of data accessibility, sharing, and interpretation. It argues that the openness of these technological interfaces can directly contribute to the socially inclusive co-management and access of citizens to common resources. ${ }^{8}$ This correlation is considered relevant to current discourse about smart communities' initiatives.

\section{Going Beyond a Singular Narrative of Using ICT to Manage Common Resources}

The introduction of this article questions the way ICT has been employed in the managing of the city and the capacity of current approaches to analyze 
the operation of the built environment as something more than a quantified system. About the integration of ICT in space, ${ }^{9}$ Manovich suggests that the result of development in smart cities is the overlaying of the physical space with "dynamically changing data." These new data layers are transforming the relationship between citizens, and the spaces they occupy, and this change, in turn, affects the way people use and appropriate urban space and therefore the operation of public space. Cybernetic theories have approached urban planning as computer architecture and established a new and more dynamic relationship between technology, spatial organization, and city-life. ${ }^{10,11}$ The primacy of technological infrastructures and solutions for envisioning and managing the city was further recognized during the digital revolution. In the late 1990s, "smart city" technologies, policies, and infrastructure methodologies emerged and were promoted, in particular, from business-orientated initiatives.

Today, data science has finally the capacity to enable open access to mobility, clean energy, water management, the food cycle, health and well-being, and citizen participation. After a century of growth (in size and complexity), major cities in Europe and the States are investing in integrating ICT in their infrastructure in order to promote their cultural polyvalence - which is physically impressed on space through time - a process that produced layering of the city and effectively generated its palimpsest. ${ }^{12}$ As they are facing new challenges, cities focus on the smart development of their building stock, infrastructure, and communities. Vienna, Bristol, London, Dublin, and many other cities are trying to do so through the integration of ICT for the monitoring of space, infrastructure usage, and operation. This enables the assessment of the impact of use patterns/citizens' behavior on the complex emergent performance and sometimes chaotic operation of their infrastructural systems and networks, as well as the delivery of relevant information to citizens and users of the space. ${ }^{13}$

Arguably, the use of ICT to control variation and to regulate the big data of the cities' infrastructure networks creates opportunities for exploitation, ${ }^{14}$ such as in the case of Urumqi, the capital of Xinjiang, China, a pilot city of China's Transit Metropolis initiative and Smart City program. Due to the political situation in the city, ${ }^{15}$ local authorities, with the central government of China, invested in ICT in order to control access to urban commons in a totalitarian way. ${ }^{16}$ Though distinct from China's model of a smart city strategy, most cities that "digitize" and interconnect their infrastructure are embracing the paradigm of "data extractivity," which is marketed as having a positive impact on citizen security. This model goes well beyond enabling people's voices to be heard and the collection of voluntarily offered opinions; rather it relies on extracting users' preferences through the analysis of observation data and from behavioral patterns.

Unlike the above counterexample, there are cities such as Bristol where the socially positive capacity of ICT for data management is a variable of parameters like spatial conditions, accessibility, sharing, information delivery, and 


\section{Amps}

interpretation, as well as the inclusiveness and openness of their operation. ${ }^{17}$ Hence, in the context of this article, a key aspect of exploiting the data management of common spaces in the built environment is the question whether the designated cybernetic systems (i.e., ICT for the management of performance-driven operation of infrastructure) can promote accessibility and sharing amongst their users. ${ }^{18}$ This article elaborates on the potential of digital tools and interfaces to enrich and expand the opportunities they offer to their users for more holistic and comprehensive access. The aim is to promote the sustainable operation of associated common spaces and in effect contribute to the social resilience of these places. ${ }^{19}$ Through the presentation of a case study, the article reflects on how these technological interfaces can become part of the concept of a "smart city" and complement current technocratic approaches and corporate visions of high tech communities.

In addition to the objective of ICT integration in space to "solve" realworld operational issues, that is, how a city functions, the application of the corporate vision of a smart city mainly focuses on how to make life in the city manageable and easier for citizens to interact with local resources. Today, major corporations such as Google, IBM, and other big tech companies (e.g., Intel, Verizon, and Esri) also invest in building smart cities, representing big data hubs for them, with the aim of defining the future of the smart city model and becoming the leaders in this important market by remaining the primary drivers of the adoption of Artificial Intelligence. These corporations develop a roadmap to respond to the challenges of six core objectives of an optimized smart community and deliver products that will offer solutions for safe, wellrun, liveable, healthy, prosperous, and sustainable communities. ${ }^{20}$ This article argues that this nexus of key targets for achieving future holistic sustainability of urban environments needs to integrate communities and citizens, but think of them not as clients and consumers, but rather as human agents, as the drivers of change. It therefore enquires how smart systems can promote civic engagement, besides real-time observation analysis, data-driven decision-making, and interactions in collaborative digital environments / software platforms. A first attempt at this enquiry is presented below through the development of case study settlements that combine (shared) smart infrastructure with an open data management platform.

Typically, design-related professionals involved in the management of the city, and the application of the smart city concept, prioritize this viewpoint when pursuing the aims and objectives of urban interventions, as exemplified by Vienna ${ }^{21}$ or Bristol, ${ }^{22}$ or even in the case of new developments, such as Foster and Partners' Masdar City ${ }^{23}$ or Songdo city near Seoul. ${ }^{24}$ They often choose to do so with a more open-ended approach which would focus on the qualities of the digitally managed space, exploiting technologies of co-management and inclusiveness. During the last few years, a campaign for an alternative approach to sustainability has gained significant traction in Europe, in the form of the so-called smart communities, ${ }^{25}$ which promote the use of ICT tools that enable social innovation. This initiative is devoted to the 
development of good practices for the use of ICT to enable the citizens of the smart city to gain better access to its resources, and the application of these practices in real-world conditions.

Maintaining a balance between these two approaches, the following sections of the article are contextualized in the focused and detailed integration of small-scale interventions in the built environment, instead of envisioning citywide cybernetic solutions for the efficient use of networks by citizens. To do so the article will focus on the presentation of the integrated systems with which a set of four new housing developments in Europe are attempting to respond to the challenges of user accessibility to the management of common resources. Through this analysis, the article aims to contribute to the discussion about the management of ICT and data used for the control of smart infrastructure, the quality of access to which can greatly affect lived experiences in cities. ${ }^{26}$

\section{Introducing Multiple Narratives in Performance-Driven Design}

Today, sensor technologies, complemented by cloud and grid computing, have finally empowered computational simulations of the micro-scales and, most importantly, the meso-scales of housing architecture. ${ }^{27}$ Observational and real-time monitoring data drive physics simulations that enable the optimization of the design, systems' integration, and operation of not only individual buildings, but also of settlements of housing units for the first time.

Alexander Klein's residential development in Bad Dórrenberg, Germany $(1928-30),{ }^{28}$ and Ernst May's series of housing projects are considered by the authors of this article as two of the early examples of settlements that were created with the aim to "optimize" (in a simplified and illustrative way) their energy consumption. The exemplar case of this approach was Ernst May's Leobschütz urban plan of "line houses" in Frankfurt, Germany (1923), which consisted of prefabricated architecture intended to be identical, but that became even more abstract and rationalized later on in the case of his rigidly geometrical Zeilenbau scheme (1930). The latter was solely geared to a narrow system of standardized solar orientation where every dwelling unit would retain the maximized conditions in relation to air, light, and space. ${ }^{29}$ What started as a graphic, formal approach to the efficient operation of bigscale housing projects, has eventually led to the contemporary practices of Performance Design ${ }^{30}$ and, with the advent of ICT, to the Sustainable Design of the Built Environment. ${ }^{31}$

Today there is a significant effort underway internationally by designers, architects, and engineers, to integrate innovative materials, technologies, and sophisticated solutions of energy conservation, production, management, and storage, as well as to gain control of all communal systems involved in the design of buildings and entire settlements. They envision that data analytics and ICT tools using observation data will form complex dependencies between variables from the bottom up, ${ }^{32,33}$ and thus will contribute to the development of integrated cybernetic systems in architecture. 
This approach seeks for new technologies and design methods (e.g., use of DesignBuilder interface with the EnergyPlus simulation engine; Rhicoceros3D with Grasshopper plugin combined with Ecotect, Radiance and EnergyPlus tools) that would enable a holistic approach to the spatial design of Near-Zero Energy buildings. In this way, their ecological benefits are an added value to the architectural design and a building's visual and material impact on its surrounding space. ${ }^{34}$ Similar methodologies have been devised for the simulation of environmental conditions on a larger scale in order to study the impact of housing units at the scale of a settlement, taking into account onsite microclimate conditions. Such tools include ENVI-met software, ${ }^{35}$ which is based on a holistic three-dimensional, non-hydrostatic, microclimate model for the simulation of surface-plant-air interactions, and CitySim software, ${ }^{36}$ which can be coupled with ENVI-met in the assessment of outdoor microclimate conditions in the urban environment to simulate surface temperature data in the outdoor areas. In addition to the simulation of the energy performance of a building or a settlement, other tools, such as SimaPro, ${ }^{37}$ Athena Impact Estimator for Buildings, ${ }^{38}$ or GaBi LCA software ${ }^{39}$ enable designers and stakeholders to apply Life Cycle Assessment (LCA) methodologies in the design process for the evaluation of the impact that the construction of the housing development would have on the environment holistically. ${ }^{40}$ In this context, green building rating systems, such as the Leadership in Energy and Environmental Design (LEED) certification, ${ }^{41}$ can assess the potential environmental impact of the design, construction, operation, and maintenance of buildings and settlements by inspiring the construction sector.

Often, the integration in the building design of ICT, sustainable concepts, advanced technologies, and high-performance materials, increases the cost of the initial design and construction and this could result in a slow spread of these solutions.

Drawing from preliminary results of ongoing research in the context of the ZERO-PLUS project, ${ }^{42,43}$ this article attempts to highlight the potential impact that i) the integration of novel optimization methodologies, ii) simulation technologies, and iii) smart-infrastructure in the design, management, and access to operation data of communal spaces in housing settlements might have for the holistic sustainability of our cities. ${ }^{44}$ The research project ZEROPLUS (acronym of 'Achieving Near Zero and Positive Energy Settlements in Europe using Advanced Energy Technology'), funded by the EU under the Horizon 2020 framework, responds to the pressing need for more resilient models of housing and sustainable built environment through the development of a comprehensive model of Net Zero Energy settlements that is currently underway in four areas across Europe: i) Peyia Village, Paphos, Cyprus, ${ }^{45}$ ii) Echirolles, Grenoble, France; iii) Granarolo dell'Emilia, Bologna, Italy; and iv) Derwenthorpe Community, York, UK. ${ }^{46}$ The four innovative residential NZE settlements (Figure 1) are an example of integrated systems design that provides access to common recourses through appropriate solutions of data 


\section{Amps}
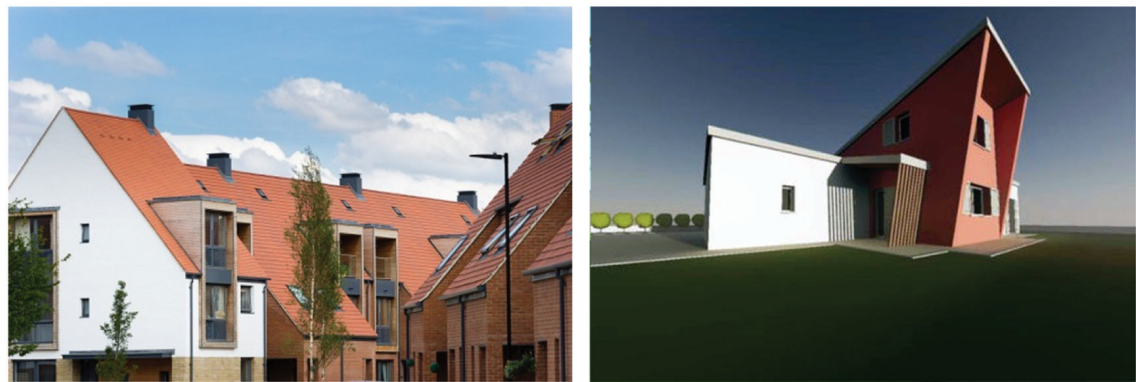

Peyia Village, Paphos, Cyprus

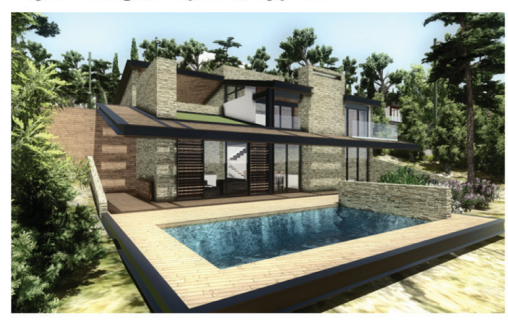

Voreppe, France

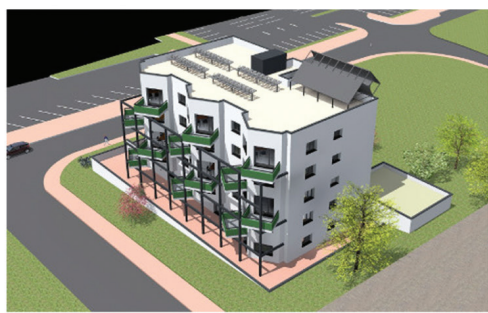

Figure 1. The four case study settlements of ZERO-PLUS. Source: ZERO-PLUS.

management. They consist of different typologies of residential buildings (ranging from villas to apartment buildings for social housing) to demonstrate the wide applicability of the ZERO-PLUS concept.

A ZERO-PLUS building is a structure that combines energy efficiency technologies, both at building and settlement scale (Figure 2), in order to meet three specific requirements: i) reduce the operational (net-regulated) energy consumption to an average of $0-20 \mathrm{kWh} / \mathrm{m}^{2}$ per year, ii) produce at least $50 \mathrm{kWh} / \mathrm{m}^{2}$ per year of renewable energy in the NZE settlement, and iii) reduce the investment cost of the ZERO-PLUS building compared to a regular Net Zero Energy Building (NZEB). Specifically, advanced building envelope components (e.g., advanced thermal insulation panels with photocatalytic properties and coatings of a highly reflective material for external walls and roofs useful to mitigates overheating risk) and innovative-high efficiency HVAC (Heating, Ventilation and Air Conditioning) systems are implemented in the ZERO-PLUS case study buildings to achieve the energy conservation target. The building and/or settlement implementation of innovative and standard Renewable Energy Systems (RES), such as wind turbines, photovoltaic panels, and solar collectors contribute to the achievement of the renewable energy production target, while thermal-energy storage systems and Energy Management Systems (EMS) are integrated with the aim of optimizing the building and settlement energy efficiency and usage. Finally, the reduction in the investment cost is achieved by moving from the building concept 


\section{Amps}

to a settlement concept. This means considering a system of houses with their interactions on a community scale instead of considering them as individual buildings.

Each of the four designs has been modified several times, by following an iterative process aimed at defining the optimal technologies combination and sizing, before simultaneously reaching the three ZERO-PLUS targets. In this iterative process, dynamic simulation software, such as $I E S V E^{47}$ and EnergyPlus, have been used since the preliminary phases of the design to model the characteristics of both building envelope and HVAC system and the occupant behavior under local weather conditions. These software programs were used to simulate the buildings' thermal-energy performance in each settlement and, eventually, ensure an accurate prediction of the energy consumption to be compared with the first ZERO-PLUS key performance indicator. ${ }^{48}$ Simultaneously, for each renewable energy system, dedicated bespoke modelling tools have been used to calculate the specific solar and wind generation based on local weather data. In this way, the total amount of energy produced at settlement level has been estimated and compared with the second ZEROPLUS key performance indicator.

One of the aspects that has also been considered in the ZERO-PLUS project is the development of the Process Information Modelling (PIM), concerning the manufacturing stage of the technologies. This has been proven to be a modelling approach useful in the planning, designing, producing, assembling, and managing of a repeatable deployment process. ${ }^{49}$

Once the optimal ZERO-PLUS design is achieved and all settlements are built, another important step is the verification of the real energy performance of the buildings and the energy production by the renewable energy systems. For this reason, a monitoring framework has been designed to assess the performance of every building and all the technologies during the operation phase of the settlements. Each monitoring equipment, which includes a meteorological station, energy meters, indoor environmental quality sensors, and other portable microclimatic stations and sensors for spot measurements, records and transfers all the key performance data to a Web-GIS platform ${ }^{50}$ able to support data acquisition, data management, and data visualization in real time. The open Web-GIS platform uses web technology to communicate and is a kind of distributed information system that can be used to share data collected from the four case study settlements and compare them to easily interpret the various results.

For each case study, the software platform analyzes data distinguished in the following activity levels: ${ }^{51}$

- Level 1: indoor environmental quality of buildings' users. This includes thermal comfort, visual comfort, and indoor air quality;

- Level 2: energy consumption profiles for both buildings and settlement;

- Level 3: energy production profiles for RES technologies. In this level, the electrical and thermal parameters of each technology will be gathered and analyzed; 
- Level 4: case studies integrated resources management and dashboard. This allows the effective management of energy demand and production profiles in order to achieve the ZERO-PLUS targets.

The integration of ICT solutions in the ZERO-PLUS settlements enables their users (inhabitants) to better manage the buildings and facilitates the operation of the settlements as a whole in a more sustainable way. According to 'The European Strategic Research Roadmap to ICT-enabled Energy-Efficiency in Buildings and Construction' (REEB) project, ${ }^{52,53}$ the different ICT solutions and applications can be divided into the following categories: i) tools for energy-efficient design and production management, ii) intelligent and integrated control, iii) user awareness and decision support, iv) energy management and training, and v) integration technologies (to enable different tools to communicate with each other). Thanks to the support of the ABB partner, ICT applications for intelligent and integrated control have been designed and implemented in the four ZERO-PLUS settlements in different ways. Specifically, as mentioned above, the main systems considered in the framework of the project are the following:

- Smart energy meters able to record the overall energy consumption, both at building and settlement level, and automatically transmit the data to the monitoring and performance analysis platform, e.g., WebGIS platform, through Ethernet cable or Wi-Fi connection of the buildings;

- Inverters to monitor the energy production of each RES technology;

- Smart sensor networks to measure and monitor indoor air temperature, relative humidity, $\mathrm{CO}_{2}$ level, occupancy, and light use (and for lighting automation);

- Energy storage system (e.g., ABB REACT - Renewable Energy Accumulator and Conversion Technology) to store any excess of energy produced by the RES technology for periods with high energy demand; and,

- Load control systems to improve the power transmission and reduce the energy loss.

The overall layout of the Web-GIS monitoring platform includes also the Cloud Server (Figure 3), operating in Linux, which incorporates:

- The database for storing the monitoring data of each settlement;

- The spatial database for the geographical data of each settlement;

- The GeoServer for displaying the geographical data;

- The Application Server, which communicates the data to the end user (for user awareness) and the Front End of the ZERO PLUS monitoring platform to ensure the buildings' performances.

Secure transfer protocols are also used to perform the communication protocol between: i) the local data acquisition unit and the Cloud Server, ii) the front end and the end user to select specific information tailored for each targeted 


\section{Amps}

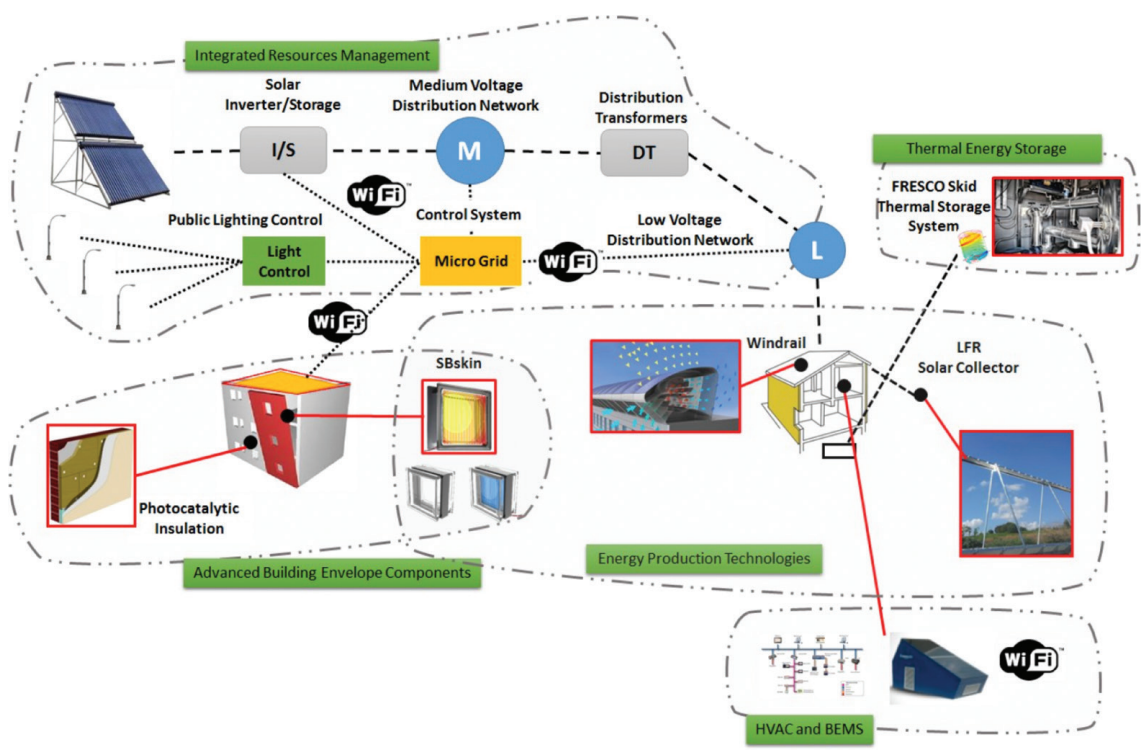

Figure 2. A comprehensive diagram of the components of the ZERO-PLUS smart infrastructure. Source: ZERO-PLUS.

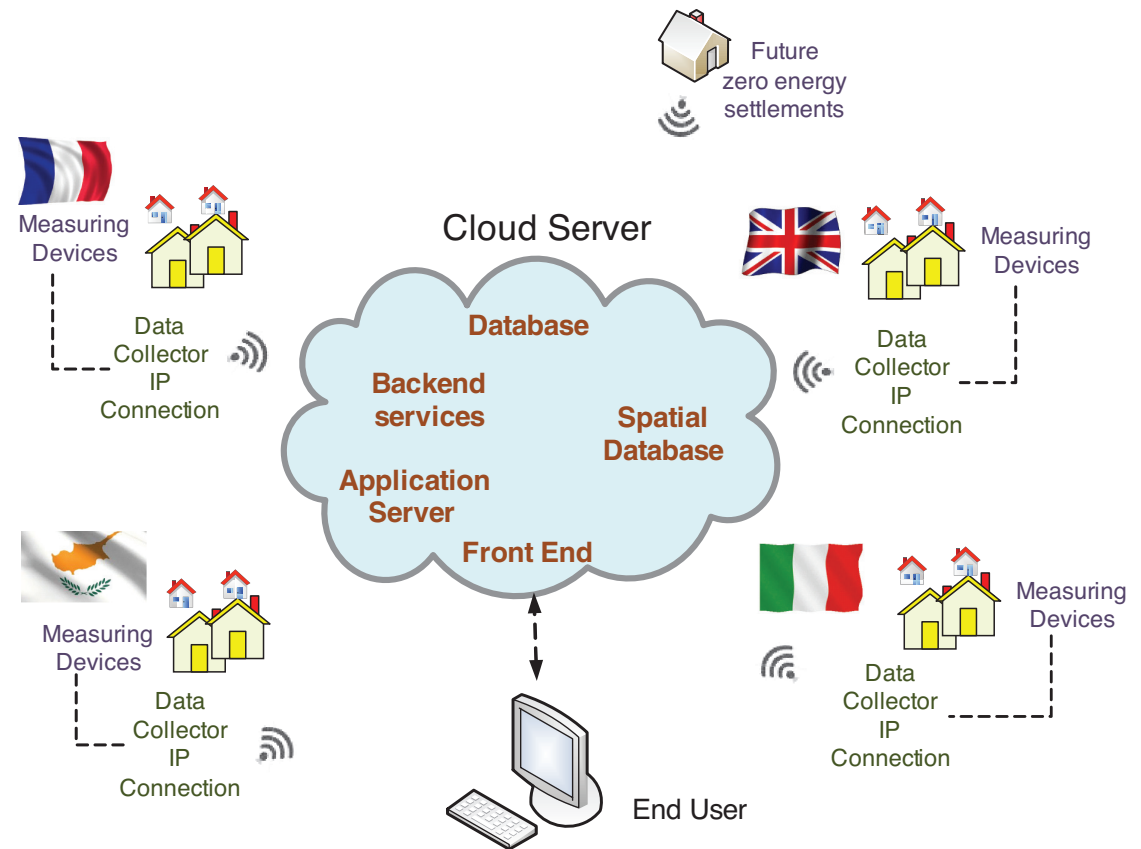

Figure 3. Overall layout of the Web-GIS monitoring platform. Source: ZERO-PLUS. 
group (e.g., building owners have access only to their own building data), and iii) various parts of the Cloud Server. Furthermore, to ensure a comprehensive understanding of the potential mistakes occurred in each phase of the settlement realization, a problem identification procedure has been integrated in the platform with the aim of detecting reasons for unsatisfactory performance and when possible take action to improve it.

\section{Accessing and Sharing Space and Data}

In light of projects such as ZERO-PLUS, and of the transformations they stimulate to current design practices, this article looks into the scope of sophisticated data management systems concerning user accessibility of communal spaces and their associated resources. It considers how the efficient management of space should not be only about lowering energy consumption. This article proposes that designers should explore new ways of complementing the various emerging technological platforms and infrastructures (e.g., smart grids) with current practices of smart communities that advocate for the potential of co-management of sustainable futures of cities. ${ }^{54}$ Smart Communities (in response to the Smart Cities initiative) are supported by the exploitation of sensor technologies for the co-management of public spaces, in order to offer free access to data through ubiquitous technologies. ${ }^{55,56}$ ICT can be used to give access to data or monitor a space and collect data of usage, and to facilitate co-management of communal spaces, as well as to allow crowdsourcing of resources. This approach could benefit greatly from open cybernetic systems that would enable users to interpret the complexity of observation and projected data regarding not only individual blocks (houses and residencies) but also the sum of them forming larger clusters, or settlements. This could be applied in a wide variety of urban conditions, in analogy to the concept of intelligent city for Barcelona's typology of blocks (super barrios). ${ }^{57}$ Furthermore, this article focuses on the complementarity of providing citizens with access to open cybernetic (smart) systems and the development of communal and public spaces that offer opportunities for appropriation and occupation in more creative ways than solely provisions of free Wi-Fi access. ${ }^{58} \mathrm{In}$ Paris, Escale Numérique (which translates as Digital Break), was designed by Mathieu Lehanneur to be installed at the Rond Point des Champs-Elysées. ${ }^{59}$ Inspired by the city's nineteenth-century network of drinking fountains, this communal structure goes beyond simply offering free Wi-Fi access, to actually become a point of stasis for citizens and tourists alike and also allows for socialization and physical interaction.

In this context, the smart technologies of the ZERO-PLUS project, at its current state of development, offer community-engaging opportunities by means of the following solutions:

a. A physical interface to the smart infrastructure planned to be installed in communal spaces of the settlements: energy regeneration systems' structures are developed to be formally and structurally integrated in the 


\section{Amps}

communal spaces of each settlement, e.g., WindRail ${ }^{60}$ (Figure 4) and FAE $\mathrm{HCPV}^{61}$ (Figure 5) systems will be exhibited by promoting the sculptural and kinetic features of their mechanical construction as a point of reference for the design and image of the main squares of the settlements; and also,

b. A digital interface developed to enable shared access: this involves the creation of the WebGIS platform for managing energy exchange between users, moving beyond the control of the regenerated energy at the house owner's level (individually), and investing in the collaboration and coordination of the ratio of the generation-use-conservation figures, through sharing data and energy (all software employed is open source and will be freely available to users) (Figure 6).

These solutions try to enrich the image and identity, of the communal spaces of the settlements in order to affect the lived experience of their users, for the same reasons the Escale Numérique transforms the Wi-Fi infrastructure in a spatial point of attraction for the users of public space in Paris. Furthermore,
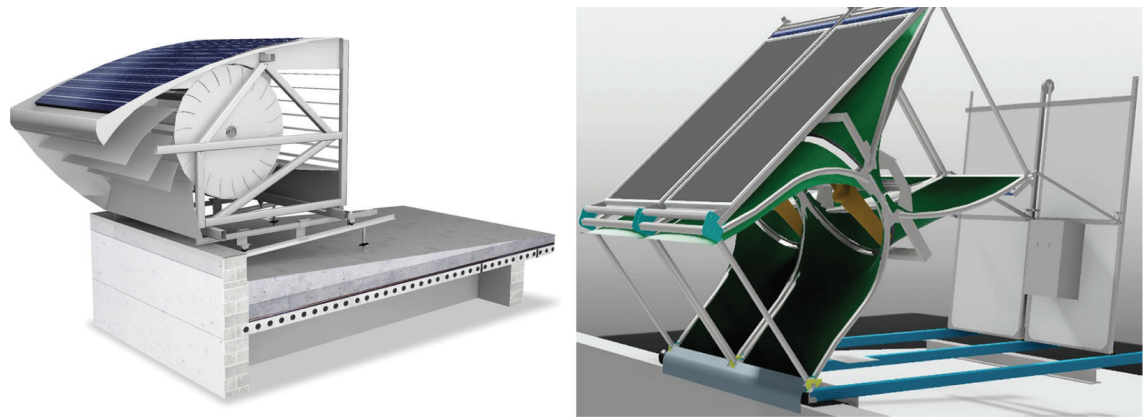

Figure 4. WindRail ${ }^{\circledR}$ C20 (left) and C30 (right) modular system is particularly suitable for Urban Farming (http://www.anerdgy.com/en/application-copy).

Source: ZERO-PLUS.
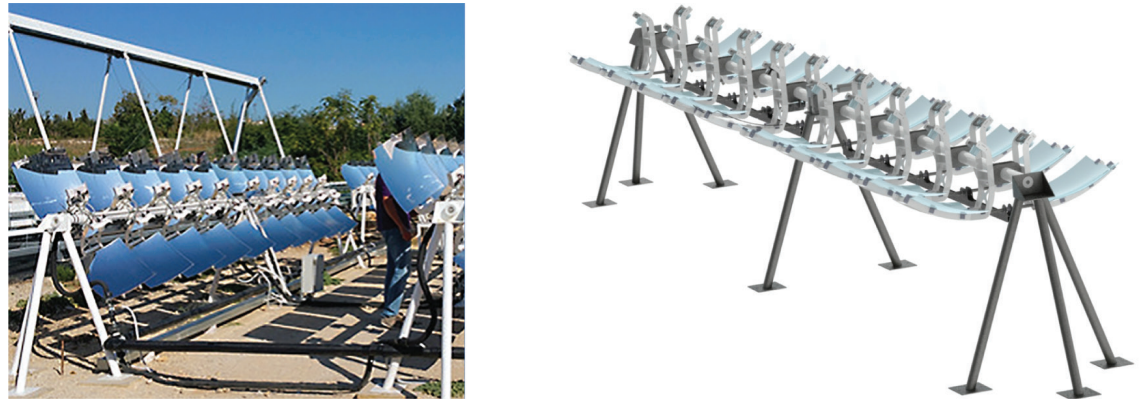

Figure 5. General view of HCPV-FAE tracker design FAE HCPVCARCA 


\section{Amps}

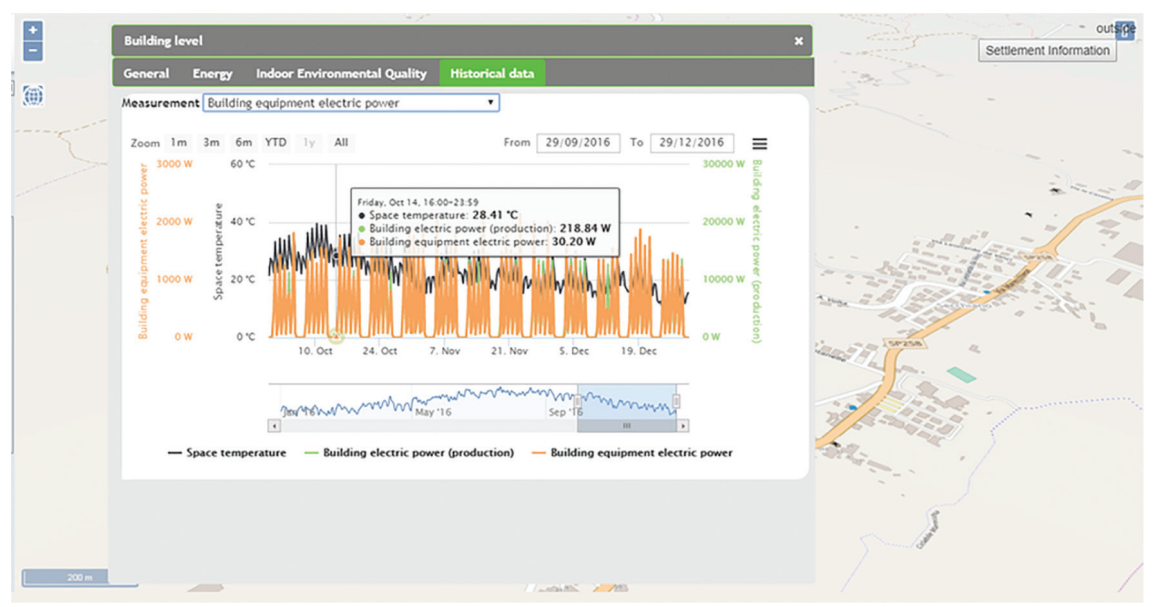

Figure 6. The ZERO-PLUS monitoring platform. Source: ZERO-PLUS.

the article suggests that this complementarity of physical and digital communal stages, becoming the interface between the individual users and the smart infrastructure, will benefit the accessibility and inclusiveness of the proposed housing model by ZERO-PLUS. This hybrid model contributes by: i) bringing together physical and digital interfaces for interaction with shared data, by positioning these interfaces in the communal spaces of the settlements in order to make them inclusive to all users; and ii) complementing pre-realization simulation tools for their infrastructure operation with post-construction technologies for occupation monitoring.

\section{Data Commons for Social Resilience}

The article concludes with an open proposition for the democratization of the big data of the built environment. Future developments of this unique integrated approach pursued by ZERO-PLUS, as presented above, should attempt to "augment" the engagement of users in its hybrid system of shared physical and digital interfaces. This would necessitate the introduction of new methods to better understand how to facilitate user engagement, a process that will offer added value to novel visualization and interpretation systems, in order to enable citizens to make sense out of all data generated or collected. This change is important as currently citizens of big cities in Europe enjoy free access to all data collected, but their capacity to partake of a role in communal activities is limited by the lack of ability to understand data.

Since the Industrial Revolution, society and culture have been subservient to technology. One of the compelling tasks today is to reverse the process and make technology serve culture and society. ${ }^{62}$ 


\section{Amps}

This article highlighted the importance of using smart technologies to activate people in settlements and cities in order to expand their interest beyond the efficient function of their houses and ease of use of public infrastructures. It was argued that said systems should exploit the capacity of ICT in open access and inclusiveness, and be coupled with physical interfaces that become the social stages that embody the shared use of communal facilities and infrastructures. In this context, and through the analysis of a real-world example, it enquires whether designers need to offer spatial programs and interfaces that make datasets intelligible, operational, and exchangeable for citizens. To what extent do authorities and designers need to give citizens a voice in the organization of the metadata?

This article argues for the embodiment of performance-driven design (and simulation) processes and ICT interfaces as not solely software-bound, but also as spatially expressed, configured, and appropriated places of community. Future developments of research, such as the ZERO-PLUS project, should include the operation and management of common resources at a second cybernetic order, integrating users' feedback in the loop through both material (spatial) and immaterial (digital) interfaces. This understanding will benefit the holistic sustainability of the built environment by generating added value, not only by making easier the use of common resources, but also by enriching citizens' lived experience of public spaces. Consequently, this approach is envisioned to contribute to the development of socially cohesive and liveable environments that will be self-organized at the meso-scale - not only in units/ residential blocks, nor at city-scale, but also at the neighborhood level. The article suggests that this process will respond to the contemporary discourse of urban acupuncture interventions. ${ }^{63}$ This inquiry contributes to the broader conversation regarding the various ways that the integration of said technological infrastructure and performance-orientated interfaces changes the structure and form of cities, and to what extent it enables equal access to common resources. ${ }^{64}$

\section{Notes}

1 K. M. Hays, ed., Architecture Theory since 1968 (Cambridge, MA: The MIT Press, 1998), 284; 522.

2 Peter Galison and Emily Ann Thompson, eds., The Architecture of Science (Cambridge, MA; London, UK: MIT Press, 1999), 2, 3.

3 Alberto Perez-Gomez, "Introduction". Architecture and the Crisis of Modern Science (Cambridge, MA: The MIT Press, 1985).

4 P. Newman and J. Kenworthy, Sustainability and Cities: Overcoming Automobile Dependence (Washington: Island Press, 1999).

5 J. Urry, "The 'System' of Automobility,". Theory, Culture \& Society 21, 4-5 (2004): 25-39.

6 A. Datta, "New Urban Utopias of Postcolonial India: 'Entrepreneurial Urbanization' in Dholera Smart City, Gujarat," Dialogues in Human Geography 5 (2015): 3-22. 
7 B. Sterling, "Stop Saying 'Smart Cities"”. The Atlantic (February 2018), accessed August 15, 2018. https://www.theatlantic.com/technology/archive/2018/02/stupid-cities/553052/.

8 G. Antonelli and G. Cappiello, eds., Smart Development in Smart Communities (London: Routledge, 2016).

9 Lev Manovich, "Learning from Prada: The Poetics of Augmented Space," in Digitextuality, ed. Anna Everett and John Caldwell (London: Routledge, 2002): 75-92.

10 M. Batty, "Big Data, Smart Cities and City Planning". Dialogues in Human Geography 3,3 (2013): 274-9.

11 C. Gershenson, "Living in Living Cities,". Artificial Life 19 (3 \& 4) (Summer/Fall 2013): 401-20.

12 W. H. Whyte, The Social Life of Small Urban Spaces (Washington, DC: Conservation Foundation, 1980).

13 Manuel de Solà-Morales, "The Strategy of Urban Acupuncture" (paper presented at the Structure Fabric and Topography Conference, Nanjing University, 2004).

14 S. Graham, "Software-Sorted Geographies," Progress in Human Geography 29,5 (2005): 1-19.

15 Eleanor Ross, "What's the History Behind China's Current Obsession with Xinjiang?” Newsweek (December 10, 2017), accessed August 15, 2018, http://www. newsweek.com/protest-xinjiang-china-muslim-central-asia-terrorism-559161.

16 C. M. Hsieh and V. C. Falkenheim, "Xinjiang”. Encyclopaedia Britannica (2018), accessed August 15, 2018, https://www.britannica.com/place/Xinjiang.

17 Antoine Zammit and Therese Kenna, eds., "Enhancing Places through Technology." Proceedings from the ICiTy conference. Valletta, Malta, 2016 (Lisbon: Edições Universitárias Lusófonas, 2017).

18 Carlos Smaniotto Costa, Alfonso Bahillo Martínez, Fernando J. Álvarez, Ina Šuklje Erjavec, Marluci Menezes, Montserrat Pallares-Barbera, "Digital Tools for Capturing User's Needs on Urban Open Spaces: Drawing Lessons from Cyberparks Project," in Citizen Empowerment and Innovation in the Data-Rich City, eds., Chiara Certomà, Mark Dyer, Lorena Pocatilu, and Francesco Rizzi (Springer International Publishing, 2017): 177-94.

19 Barbara Marušić, "Analysis of Patterns of Spatial Occupancy in Urban Open Space Using Behaviour Maps and GIS,” Urban Design International 16 (2010): $36-50$.

20 Smart Communities, Make Your Community Smarter \& More Efficient (January 2017), accessed August 15, 2018, http://www.esri.com/smart-communities.

21 Smart City Wien, Smart City Wien (December 2016), accessed August 15, 2018, https://smartcity.wien.gv.at/site/en/.

22 Bristol Is Open, Bristol Is Open - Open Programmable City (January 2017), accessed August 15, 2018. http://www.bristolisopen.com.

23 Foster and Partners 2016. Masdar City (November 2016), accessed August 16, 2018. http://www.fosterandpartners.com/projects/masdar-development.

24 BBC News 2017. Tomorrow's Cities: Just How Smart is Songdo? (July 2017), accessed August 16, 2018. http://www.bbc.com/news/technology-23757738; 
KOREA EXPOSÉ 2016. Songdo: No Man's City (October 2016), accessed August 16, 2018, https://koreaexpose.com/songdo-no-mans-city/.

25 Marketplace of the European Innovation Partnership on Smart Cities and Communities, accessed August 16, 2018. https://eu-smartcities.eu. (2015). See "Action Cluster" and then "Citizen Engagement."

26 European Union, LEIPZIG CHARTER on Sustainable European Cities, (2007): 1-7, accessed August 16, 2018, http://ec.europa.eu/regional_policy/archive/ themes/urban/leipzig_charter.pdf.

27 M. Noguchi, A. Athienitis, V. Delisle, J. Ayoub, and B. Berneche, "Net Zero Energy Homes of the Future: A Case Study of the ÉcoTerra House in Canada." Renewable Energy Congress 2008.

28 Jean-Louis Cohen, "Sublime, Inevitably Sublime: The Appropriation of Technical Objects," in Le Corbusier: The Art of Architecture, eds., Alexander von Vegesack and Mateo Kries (Weil am Rhein, Germany: Vitra Design Museum, 2007), 220 $32,223$.

29 Susan R. Henderson, Building Culture: Ernst May and the Frankfurt Initiative, 1926-1931 (Bern, Frankfurt, London, New York: Peter Lang, 2013).

30 X Shi, Front Archit. Civ. Eng. China 4, 512 (2010), accessed August 16, 2018, https://doi.org/10.1007/s11709-010-0090-6.

31 A. Synnefa, M. Laskari, R. Gupta, A. L. Pisello, and M. Santamouris, "Development of Net Zero Energy Settlements Using Advanced Energy Technologies," Procedia Engineering 180 (2017):1388-401.

32 C. Fan, F. Xiao, and S. Wang, "Development of Prediction Models for Next-Day Building Energy Consumption and Peak Power Demand Using Data Mining Techniques," Applied Energy 127 (2014): 1-10.

33 S. Papantoniou, D. Kolokotsa, and K. Kalaitzakis, "Building Optimization and Control Algorithms Implemented in Existing BEMS Using a Web-Based Energy Management and Control System," Energy and Buildings 98 (2014): 45-55.

34 D. Hough and C. Kratz, "Can 'Good' Architecture Meet the Market Test?" Journal of Urban Economics 14(1983): 40-5.

35 ENVI_MET, Decoding Urban Nature, January 2017, accessed August 16, 2018, www.envi-met.com.

36 LESO-PB, CitySim Software, February 2015, accessed August 16, 2018, https:// citysim.epfl.ch/.

37 SimaPro, SimaPro, the world's leading LCA software, January 2017, accessed August 18, 2018, https://simapro.com/.

38 Athena Sustainable Materials Institute, IE for buildings, January 2017, accessed August 18, 2018, http://www.athenasmi.org/our-software-data/impact-estimator/.

39 GaBi Software, Life Cycle Assessment LCA Software, January 2017, accessed August 18, 2018, http://www.gabi-software.com/malaysia/index/.

40 E. Bonamente, M. C. Merico, S. Rinaldi, G. Pignatta, A. L. Pisello, F. Cotana, and A. Nicolini, "Environmental Impact of Industrial Prefabricated Buildings: Carbon and Energy Footprint Analysis Based on an LCA Approach," Energy Procedia 61 (2014): 2841-44. 
41 USGBC 2016. LEED, November 2016, accessed August 18, 2018, https://new. usgbc.org/leed.

42 ZERO-PLUS project received funding from European Union's Horizon 2020 research and innovation program in 2015 under grant agreement No. 678407. The project is coordinated by the National and Kapodistrian University of Athens and the consortium includes three major types of partners: i) Universities (National and Kapodistrian University of Athens, The Cyprus Institute, Technical University of Munich, Ben-Gurion University of the Negev, OxfordBrookes University, University of Perugia, and Technical University of Crete), ii) Technology providers (ABB, Anerdgy, Arca, British Gas, and Fibran), and iii) Case study owners (Contedil di Ricco Maria \& C., S.A.S., JRHT, OPAC38, George Vassiliou Ltd), accessed August 18, 2018, http://zeroplus.org; accessed August 18, 2018, http://www.buildup.eu/en/news/overview-achieving-near-zero-and-positive-energy-settlements-europe-using-advanced-energy-0.

43 A. L. Pisello, C. Piselli, G. Pignatta, C. Fabiani, F. Ubertini, F. Cotana, and M. Santamouris. "Net Zero Energy Settlement in Europe: First Findings of the ZERO-PLUS Horizon 2020 Project". Proceeding from the 16th CIRIAF National Congress (Assisi, Italy, April 2016).

44 M. Santamouris, N. Gaitani, A. Spanou, M. Saliari, K. Giannopoulou, T. Vasilakopoulou, and K. Kardomateas, "Using Cool Paving Materials to Improve Microclimate of Urban Areas: Design Realization and Results of the Flisvos Project," Building and Environment 53 (2012): 128-36.

45 M. K. Dracou, M. Santamouris, C. N. Papanicolas, "Achieving Nearly Zero Energy Buildings in Cyprus, Through Building Performance Simulations, Based on the Use of Innovative Energy Technologies,”. Energy Procedia 134 (2017): 636-44.

46 R. Gupta and M. Gregg, "Assessing Energy Use and Overheating Risk in Net Zero Energy Dwellings in UK,” Energy and Buildings 158 (2018): 897-905.

47 IES VE (Integrated Environmental Solutions Virtual Environment) thermal calculation and dynamic simulation software was selected as it is an approved industry standard, audited by the Chartered Institution of Building Services Engineers and the United Kingdom Accreditation Service as well as being an accredited software for producing Energy Performance Certificates (EPCs) by the Building Research Establishment (BRE), cf. IES 2017.

48 The last cost-based ZERO-PLUS target has been continuously evaluated for each case study, from the preliminary stage to the executive stage of the design, by means of specific tools (Shubin et al., 2017). In particular, three tools have been used: i) the cost control tool for the initial track of the technologies, ii) the change management tool for the examination of potential changes in the design, and iii) a tool that performs an accurate Life Cycle Cost (LCC) analysis of each technology and suggests the optimal configuration based on cost and energy performance targets. Furthermore, additional analysis aimed at estimating the $\mathrm{CO}_{2}$ emissions in each settlement, has been carried out by using dedicated and simplified tools based on the Life Cycle Assessment (LCA) methodology.

49 W. Pan, K. Langosh, and T. Bock, "Development of the Process Information Modelling in the Construction Project: A Case Study of the ZERO-PLUS 
Project". Proceedings from the 34th International Symposium on Automation and Robotics in Construction (ISARC 2017) (Taipei, Taiwan, June 2017).

50 K. Gobakis, A. Mavrigiannaki, K. Kalaitzakis, and D. D. Kolokotsa, "Design and Development of a Web-Based GIS Platform for Zero Energy Settlements Monitoring," Energy Procedia 134 (2017): 48-60.

51 ZERO-PLUS, D7.1 Design of a Monitoring Framework for Performance Assessment during Operation, (December 2017), accessed August 18, 2018, http:// zeroplus.org.

52 REEB project was carried out within FP7, the 7th EU Framework Programme for Research and Technology Development and finished in 2010.

53 REEB. D4.2 Strategic Research Roadmap for ICT-Supported Energy Efficiency in Construction (2009).

54 Chiara Certomà, Mark Dyer, Lorena Pocatilu, and F. Rizzi, eds., Citizen Empowerment and Innovation in the Data-Rich City (Springer International Publishing, 2001).

55 Helena Lindskog, Smart Communities Initiatives (2004), accessed August 18, 2018, https://www.researchgate.net/publication/228371789_Smart_communities_ initiatives.

56 National Academies of Sciences, Engineering, and Medicine, "Building Smart Communities for the Future". Proceedings of a Workshop - in Brief (2016). Washington, DC: The National Academies Press.

57 IaaC, SUPERBARRIO (January 2017), accessed August 18, 2018, http://superbarrio.iaac.net.

58 CityBridge, LinkNYC (January 2017), accessed August 18, 2018, https://www. link.nyc.

59 Mathieu Lehanneur, Escale-numerique (October 2016), accessed August 18, 2018, http://www.mathieulehanneur.fr/project/escale-numerique.

60 ANERDGY's WindRail® modular building-based system combines renewable energy, multiple design options and cost-effectiveness in a single solution. WindRail produces local renewable energy by combining wind and sun; in particular it uses three energy sources in one solution: pressure difference, wind, and solar radiation.

61 FAE technology exploits the capacity of CPV systems to focus a wide area impacted by the sun radiation on a small area occupied by one or more high efficiency photovoltaic cells (up to $44 \%$ of conversion rate) to generate electricity. They need a precise sun-tracking support mounting and a cooling system able to keep the cell at the optimal working temperature. Capturing the waste heat increases the overall efficiency of the system that combines heat and power (CHP) solar systems, cf. Paredes et al. 2015.

62 B. Bagdikian, "The Endless Chain," in The Media Monopoly (Chapter 1). (Boston: Beacon Press, 2004), 20th edition: 239-40.

63 Jaime Lerner, Urban Acupuncture (Washington, DC: Island Press, 2014).

64 D. Chipperfield, K. Long, and S. Bose, eds., Common Ground: A Critical Reader: Venice Biennale of Architecture 2012 (Venice, Italy: Marsilio, 2012). 


\section{Amps}

\section{Bibliography}

Antonelli, G., and G. Cappiello, eds. Smart Development in Smart Communities. London: Routledge, 2016.

Athena Sustainable Materials Institute, IE for buildings, January 2017. Accessed August 18, 2018. http://www.athenasmi.org/our-software-data/impact-estimator/.

Aurigi, A. "Reflections Towards an Agenda for Urban-Designing the Digital City." Urban Design International 18, 2:131-44.

Bagdikian, B. "The Endless Chain.” In The Media Monopoly (Chapter 1). Boston: Beacon Press, 2004, 20th edition: 239-40.

Batty, M. "Big Data, Smart Cities and City Planning." Dialogues in Human Geography 3,3 (2013): 274-9.

BBC News. Tomorrow's Cities: Just How Smart is Songdo? July 2017. Accessed August 16, 2018. http://www.bbc.com/news/technology-23757738.

Benevolo, L. History of Modern Architecture: The Modern Movement. Cambridge: MIT Press, 1971.

Bonamente, E., M. C. Merico, S. Rinaldi, G. Pignatta, A. L. Pisello, F. Cotana, and A. Nicolini. "Environmental Impact of Industrial Prefabricated Buildings: Carbon and Energy Footprint Analysis Based on an LCA Approach.” Energy Procedia 61 (2014): 2841-44.

Bristol Is Open, Bristol Is Open - Open Programmable City. January 2017. Accessed August 16, 2018. http://www.bristolisopen.com.

Burgess, J., and M. Nye, "Re-Materialising Energy Use Through Transparent Monitoring Systems.” Energy Policy 36 (2008): 4454-59.

Certomà, Chiara, Mark Dyer, Lorena Pocatilu, and F. Rizzi, eds. Citizen Empowerment and Innovation in the Data-Rich City. Springer International Publishing, 2001.

Chipperfield, D., K. Long, and S. Bose, eds. Common Ground: A Critical Reader: Venice Biennale of Architecture 2012. Venice, Italy: Marsilio, 2012

CityBridge, LinkNYC. January 2017. Accessed August 18, 2018. https://www.link.nyc.

Cohen, Jean-Louis. "Sublime, Inevitably Sublime: The Appropriation of Technical Objects." In Le Corbusier: The Art of Architecture, edited by Alexander von Vegesack and Mateo Kries. Weil am Rhein, Germany: Vitra Design Museum, 2007.

Colquhoun, Alan. "Plateau Beaubourg." In Essays in Architectural Criticism: Modern Architecture and Historical Change, edited by Alan Colquhoun, Peter Eisenman, and Kenneth Frampton, 110-19. Cambridge, Mass: MIT Press, 1981.

Datta, A. "New Urban Utopias of Postcolonial India: 'Entrepreneurial Urbanization' in Dholera Smart City, Gujarat." Dialogues in Human Geography 5 (2015): 3-22.

de Solà-Morales, Manuel. "The Strategy of Urban Acupuncture” Paper presented at the Structure Fabric and Topography Conference, Nanjing University, 2004.

Dracou, M. K., M. Santamouris, and C. N. Papanicolas. "Achieving Nearly Zero Energy Buildings in Cyprus, Through Building Performance Simulations, Based on the Use of Innovative Energy Technologies." Energy Procedia 134 (2017): 636-44.

ENVI_MET. Decoding Urban Nature. January 2017. www.envi-met.com. 


\section{Amps}

European Union. LEIPZIG CHARTER on Sustainable European Cities. 2007: 1-7. Accessed August 16, 2018. http://ec.europa.eu/regional_policy/archive/themes/ urban/leipzig_charter.pdf.

Fan, C., F., Xiao, and S. Wang. "Development of Prediction Models for Next-Day Building Energy Consumption and Peak Power Demand Using Data Mining Techniques." Applied Energy 127 (2014): 1-10.

Foster and Partners 2016. Masdar City. November 2016. Accessed August 16, 2018. http://www.fosterandpartners.com/projects/masdar-development.

Foth M., M. Brynskov and T. Ojala, eds. Citizen's Right to the Digital City: Urban Interfaces, Activism, and Placemaking. Singapore: Springer, 2015.

GaBi Software, Life Cycle Assessment LCA Software. January 2017. Accessed August 18, 2018. http://www.gabi-software.com/malaysia/index/.

Galison, Peter, and Emily Ann Thompson, eds. The Architecture of Science. Cambridge, MA; London, UK: MIT Press, 1999.

Gershenson, C. "Living in Living Cities." Artificial Life 19 (3 \& 4) (Summer/Fall 2013): 401-20.

Gobakis, K., A. Mavrigiannaki, K. Kalaitzakis, and D. D. Kolokotsa. "Design and Development of a Web-Based GIS Platform for Zero Energy Settlements Monitoring," Energy Procedia 134 (2017): 48-60.

Graham, S. "Software-Sorted Geographies." Progress in Human Geography 29 (5) (2005): 1-19.

Groat, Linda, and David Wang. Architectural Research Methods. New York, NY: John Wiley, 2002.

Gupta, R., and M. Gregg, "Assessing Energy Use and Overheating Risk in Net Zero Energy Dwellings in UK." Energy and Buildings 158 (2018): 897-905.

Hampton, K. N., and N. Gupta. "Community and Social Interaction in the Wireless City: Wi-Fi Use in Public and Semi- Public Spaces". New Media \& Society 10,6 (2008): 831.

Hampton, K. N., O. Livio, and L. Sessions. "The Social Life of Wireless City: Wi-Fi Use, Social Network, and the Public Realm." Journal of Communication 60,4 (2010): 701-22.

Hays, K. M. ed., Architecture Theory since 1968. Cambridge, MA: The MIT Press, 1998.

Hollands, R. G. "Will the Real Smart City Please Stand Up?" City: Analysis of Urban Trends, Culture, Theory, Policy, Action 12,3 (2008): 303-20.

Henderson, Susan R. Building Culture: Ernst May and the Frankfurt Initiative, 19261931. Bern, Frankfurt, London, New York: Peter Lang, 2013.

Hough, D., and C. Kratz. "Can 'Good' Architecture Meet the Market Test?” Journal of Urban Economics 14 (1983): 40-5.

Hsieh, C. M. and V. C. Falkenheim. "Xinjiang". Encyclopadia Britannica (2018). Accessed August 16, 2018. https://www.britannica.com/place/Xinjiang.

IES 2017. Integrated Environmental Solutions, January 2017. Accessed August 16, 2018. https://www.iesve.com.

IaaC, SUPERBARRIO. January 2017. Accessed August 18, 2018. http://superbarrio. iaac.net. 
Jackson, T. Motivating Sustainable Consumption: A Report to the Sustainable Development Research Network. SDRN, 2004.

KOREA EXPOSÉ. Songdo: No Man's City. October 2016. Accessed August 16, 2018. https://koreaexpose.com/songdo-no-mans-city/.

Lehanneur, Mathieu. Escale-numerique. October 2016. Accessed August 18, 2018. http://www.mathieulehanneur.fr/project/escale-numerique.

Lerner, Jaime. Urban Acupuncture. Washington, DC: Island Press, 2014.

LESO-PB. CitySim Software. February 2015. Accessed August 18, 2018. https:// citysim.epfl.ch/.

Lindskog, Helena. Smart Communities Initiatives. 2004. Accessed August 18, 2018. https://www.researchgate.net/publication/228371789_Smart_communities_initiatives.

Mallgrave, Harry Francis, and Christina Contandriopoulos. Architectural Theory, Vol. 1. Malden, MA; Oxford: Blackwell, 2005.

Manovich, Lev."Learning from Prada: The Poetics of Augmented Space." In Digitextuality, edited by Anna Everett and John Caldwell, 75-92. London: Routledge, 2002.

Marketplace of the European Innovation Partnership on Smart Cities and Communities. 2015. https://eu-smartcities.eu.

Marušić, Barbara. "Analysis of Patterns of Spatial Occupancy in Urban Open Space Using Behaviour Maps and GIS,” Urban Design International 16 (2010): 6-50.

Migayrou, Frédéric, and Zeynep Mennan. Architectures Non Standard. Paris: Centre Pompidou, 2003.

Mumford, Eric. The CIAM Discourse on Urbanism, 1928-1960. Cambridge, MA: MIT Press, 2002.

National Academies of Sciences, Engineering, and Medicine. "Building Smart Communities for the Future." Proceedings of a Workshop - in Brief. Washington, DC: The National Academies Press, 2016.

Newman, P., and J. Kenworthy. Sustainability and Cities: Overcoming Automobile Dependence. Washington: Island Press, 1999.

Noguchi, M., A. Athienitis, V. Delisle, J. Ayoub, and B. Berneche. "Net Zero Energy Homes of the Future: A Case Study of the ÉcoTerra House in Canada." Renewable Energy Congress 2008.

Offenhuber D., and C. Ratti. 2014. Decoding the City: How Big Data Can Change Urbanism. Basel: Birkhauser Verlag AG, 2014.

Owens, S., and L. Driffill. "How to Change Attitudes and Behaviours in the Context of Energy". Energy Policy 36 (2008): 4412-18.

Pan, W., K. Langosh, and T. Bock. "Development of the Process Information Modelling in the Construction Project: A Case Study of the ZERO-PLUS Project". Proceedings from the 34th International Symposium on Automation and Robotics in Construction. ISARC 2017. Taipei, Taiwan, June 2017.

Papantoniou, S., D. Kolokotsa, and K. Kalaitzakis, "Building Optimization and Control Algorithms Implemented in Existing BEMS Using a Web-Based Energy Management and Control System," Energy and Buildings 98 (2014): 45-55.

Paredes, F., F. M. Montagnino, P. Salinari, G. Bonsignore, S. Milone, S. Agnello, M. Barbera, F. M. Gelardi, L. Sciortino, A. Collura, U. L. Cicero, and M. Cannas. 


\section{Amps}

"Combined Heat and Power Generation with a HCPV System at 2000 Suns". 11th International Conference on Concentrator Photovoltaic Systems AIP Conf. Proc: 1679, 100003-1-100003-6. AIP Publishing LLC, 2015.

Perez-Gomez, Alberto. Introduction to Architecture and the Crisis of Modern Science by Perez-Gomez. Cambridge, MA: The MIT Press, 1985.

Pisello, A. L., C. Piselli, G. Pignatta, C. Fabiani, F. Ubertini, F. Cotana, and M. Santamouris. "Net Zero Energy Settlement in Europe: First Findings of the ZEROPLUS Horizon 2020 Project". Proceeding from the 16th CIRIAF National Congress. Assisi, Italy, April 2016.

Ross, Eleanor. "What's the History Behind China's Current Obsession with Xinjiang?" Newsweek. December 10, 2017. Accessed August 16 2018. http://www.newsweek. com/protest-xinjiang-china-muslim-central-asia-terrorism-559161.

Santamouris, M., N. Gaitani, A. Spanou, M. Saliari, K. Giannopoulou, T. Vasilakopoulou, and K. Kardomateas, "Using Cool Paving Materials to Improve Microclimate of Urban Areas: Design Realization and Results of the Flisvos Project." Building and Environment 53 (2012): 128-36.

Shi, X. Front Archit. Civ. Eng. China 4, 512 (2010). Accessed August 16, 2018. https:// doi.org/10.1007/s11709-010-0090-6.

Shubin, S., S. Isaac, and G. Rabinowitz. "Control and Optimization Tools for the Incorporation of Innovative Technologies in Net Zero Energy Settlement Design." Proceedings from the 34th International Symposium on Automation and Robotics in Construction (ISARC 2017). Taipei, Taiwan, June 2017.

SimaPro. SimaPro, The World's Leading LCA Software. January 2017. Accessed August 16, 2018. https://simapro.com/.

Smaniotto Costa, Carlos, Alfonso Bahillo Martínez, Fernando J. Álvarez, Ina Šuklje Erjavec, Marluci Menezes, Montserrat Pallares-Barbera. "Digital Tools for Capturing User's Needs on Urban Open Spaces: Drawing Lessons from Cyberparks Project." In Citizen Empowerment and Innovation in the Data-Rich City, edited by Chiara Certomà, Mark Dyer, Lorena Pocatilu, and Francesco Rizzi, 177-94. Springer International Publishing, 2017.

Smart City Wien. Smart City Wien. December 2016. Accessed August 16, 2018. https:// smartcity.wien.gv.at/site/en/.

Smart Communities. Make Your Community Smarter \& More Efficient. January 2017. Accessed August 16, 2018. http://www.esri.com/smart-communities.

Sterling, B. "Stop Saying 'Smart Cities"'. The Atlantic (February 2018). Accessed August 15, 2018. https://www.theatlantic.com/technology/archive/2018/02/stupid-cities $/ 553052 /$.

Synnefa, A., M. Laskari, R. Gupta, A. L. Pisello, and M. Santamouris, "Development of Net Zero Energy Settlements Using Advanced Energy Technologies," Procedia Engineering 180 (2017):1388-401.

Tzonos, Panos. Four Value Systems in the Theory of Contemporary Architecture. Thessaloniki: University Studio Press, 1985.

Urry, J. “The 'System' of Automobility." Theory, Culture \& Society 21, 4-5 (2004): $25-39$.

USGBC. LEED, November 2016. Accessed August 18, 2018. https://new.usgbc.org/leed. 


\section{Amps}

Whyte, W. H. The Social Life of Small Urban Spaces. Washington, DC: Conservation Foundation, 1980.

Zammit, Antoine, and Therese Kenna, eds. "Enhancing Places through Technology." Proceedings from the ICiTy conference, Valletta, Malta, 2016. Lisbon: Edições Universitárias Lusófonas, 2017.

ZERO PLUS Accessed August 18, 2018. http://zeroplus.org. Accessed August 18, 2018. http://www.buildup.eu/en/news/overview-achieving-near-zero-and-positive-energy-settlements-europe-using-advanced-energy- 0 . 